\title{
IMPLEMENTATION OF AQIDAH AKHLAK LEARNING USING THE CONTEXTUAL LEARNING MODEL IN MA AN-NUR MALANGBONG GARUT DISTRICT
}

\author{
Lalan Jaelani \\ Pascasarjana UIN Sunan Gunung Djati Bandung \\ Email: Lalanaja1@gmail.com
}

\begin{abstract}
Aqidah learning morality that there is prioritizing cognitive aspects, both concerning the divinity and humanity that want to be instilled and developed into students themselves. The purpose of this study is to find out and analyze; (1) Aqidah moral learning design using a contextual approach, (2) implementation of Aqidah morality learning (3) evaluating Aqidah morality learning using a contextual learning approach, (4) supporting and inhibiting factors, (5) advantages and disadvantages and (6) the effectiveness of contextual learning approaches in the subjects of Aqidah Morals to shape the Islamic character of students. Using descriptive qualitative methods with the type of analytic descriptive research. The data collection tool was obtained using: observation, interview, and study documentation. The data analysis procedures performed are data reduction, data presentation, drawing conclusions or verification. The results of this study show that the design of contextual learning in the subjects of Aqidah Akhlak uses the components of the Contextual Teaching and Learning (CTL) stages, namely constructivism (constructivism), finding (inquiry), asking (questioning), learning community (learning community), modelling (modelling), reflection (reflection), and actual assessment (authentic assessment). The implementation of Aqidah Akhlak learning by using a contextual approach in MA An-Nur Malangbong is following the learning design. While the inhibiting factors include: difficulty analyzing individual student differences, not all are suitable for using a contextual approach, as well as difficulties in conducting evaluation and time management that requires a lot of time. Meanwhile, the contextual approach to the subjects of Aqidah Akhlak carried out at MA An-Nur Malangbong for the formation of Islamic character in students can be said to be very effective. This can be seen from the increase in their learning outcomes for the five Islamic characters analyzed, namely honesty, discipline, responsibility, cooperation and courtesy, experiencing an average increase from 2.44 to 3.3 .
\end{abstract}

Keywords: Aqidah, Constitutional, Morals

\section{INTRODUCTION}

The education process is believed by education experts as an effort to humanize humans (Tafsir, 2017). In other words, helping humans become real human beings. These efforts are carried out with full awareness and planning, to achieve the goals set (Muhibbin, 2010).

The concept implies that education places humans according to their human proportions and nature (Ash'ari, Ekayati, \& Matulessy, 2014) or following their nature, so that humans can find their true identity, and can further find the transcendent essence that has been created it (Hermayanti, Budimansyah, \& Lenggana, 2018). So as a consequence of this concept, the education process must cover all aspects, all aspects of human life and reflect humane processes.

The success of an educational process is determined by the implementer of education itself, namely the teacher. Because it is the teacher who has a significant role in the education process. Teachers as implementers of education have a very central and strategic position (Al Baehaqi \& Haris, 2015), because

* Copyright (c) 2019 Lalan Jaelani

This work is licensed under a $\underline{\text { Creative Commons Attribution-ShareAlike 4.0 International License. }}$

Received: 15 May 2019; Revised: 15 Juny 2019; Accepted: 30 Juny 2019 
IJIK, Vol. 9 No. 2: 48-60

Implementation Of Aqidah Akhlak Learning Using The Contextual Learning Model In Ma An-Nur

Malangbong Garut District

Lalan Jaelani

in the hands of teachers lies the possibility of success or not the achievement of educational goals in schools (Pransiska, 2016).

The learning process here is defined as a process for learning a person or group of people through various efforts (efforts) and various strategies, approaches and methods, towards achieving the planned goals (Zayadi \& Majid, 2016). Learning can also be seen as teacher activities programmed in instructional design (instructional design) to make students learn actively and provide learning resources. Thus, learning is a planned activity that conditions and stimulates a person to be able to learn well following the learning objectives.

To achieve these learning objectives, we need a learning strategy and approach that can deliver in the direction of an interesting and enjoyable learning process because the best learning can challenge and stimulate students so that they want to learn. Thus, the teacher must be able to analyze learning strategies and approaches that are seen to be able to teach students in the learning process, so that learning objectives can be achieved effectively and learning outcomes can be further improved.

Considering that what is expected in achieving learning objectives is students, every effort to find alternative approaches to learning must always be based on the interests of learners. In other words, the alternative approach must reflect an attempt to find alternatives for the interests of students to facilitate in achieving learning objectives. Because after all the activities of the learning process not only emphasizes what (material) students must learn (understanding concepts), but rather emphasizes how students should learn (experience learning) (Zayadi \& Majid, 2016).

To achieve the goals or success of learners, there are at least five things or five main variables that need attention, namely: (1) The teacher must actively involve students; (2) the teacher must be able to attract students 'interests and students' attention; (3) teachers must be able to arouse students' motivation; (4) developing the principle of individuality; and (5) demonstrate in the learning process (Darmadi, 2016).

One of the learning strategies and approaches offered and seen as meeting the above criteria is through a contextual teaching and learning approach (contextual learning approach) or often abbreviated as CTL.

Contextual teaching and learning is a learning approach that emphasizes the process of full involvement of students to be able to find the material being learned and relate it to real-life situations, thus encouraging them to apply it in their lives (Hadi, 2012).

According to Use, a contextual learning approach is a learning approach that emphasizes the relationship between learning material and the real world of students' lives, so students can connect and apply learning outcomes competencies in daily life (Uce, 2016).

Contextual learning is one of the learning strategies built on the assumption that knowledge is constructed by humane. For this reason, a constructivism learning approach is developed that opens opportunities as wide as possible for students to empower themselves. Because in modern educational theory, the best way of learning is that students actively construct their understanding.

Therefore, in the context of applying this contextual approach, the habits of teachers who act in class 'stage' and students only watch what the teacher plays, it is time to be changed into students who are actively learning, while teachers only guide up close (Darmadi, 2016).

The contextual learning approach is applied to the learning process of the Aqidah morality is motivated by a concern with the conditions of the learning process that occurs in the country, which only gives birth to output that is rich in ideas but very poor with the application. They all understand very well what is learned but do not have the will to apply it in everyday life. 
IJIK, Vol. 9 No. 2: 48-60

Implementation Of Aqidah Akhlak Learning Using The Contextual Learning Model In Ma An-Nur

Malangbong Garut District

Lalan Jaelani

By using a contextual learning approach to the subject of Aqidah morality especially students will directly construct knowledge from their daily experiences. Thus, in addition to understanding the material, they will become more accustomed to applying it in their daily lives, so that gradually the habit will shape themselves into character.

Also, the application of contextual approaches in learning Aqidah Akhlak aims to want to teach students with religious sciences, specifically Aqidah Akhlak, by involving them fully to be able to find the material being studied and relate it to real-life situations so that it will encourage them to apply it in real life which will then form an Islamic character in themselves.

For this reason, the author feels interested in researching contextual learning, especially about the learning process of the Aqidah Morals in Madrasah Aliyah Annur Malangbong, Garut Regency. Furthermore, for this study, the authors formulated in a thesis title, "The Effectiveness of Contextual Learning Approaches in Aqidah Morals for Shaping Islamic Students' Characteristics (Research in Madrasah Aliyah Annur Malangbong Garut Regency)".

\section{METHODOLOGY}

This study uses a qualitative approach, which is data collected in the form of words, images, not numbers (Sugiyono, 2013). Research on the effectiveness of the use of contextual learning approaches in learning Aqidah Morals using descriptive methods. This method is used because it is directly related to life, especially in MA Annur Malangbong Garut. With this method, it is expected to be interpreted in depth the meaning and content.

This study includes qualitative research, namely research that produces descriptive data from people and actors that can be observed. By using descriptive-analytic methods, this research is more directed at a holistic individual setting, meaning that it does not isolate individuals or organizations into hypothetical variables, but rather views it as a whole.

This qualitative research is analytical descriptive which seeks to explain systematically about the things that are the focus of the research problem by looking at accurate and factual data sources. Descriptive analytical research is not limited to data collection or compilation but includes analysis and interpretation of data.

The data collection techniques that the author will do are observation, interview and documentation techniques, with the following description:

Observations, interviews (Head of Madrasah Aliyah Annur Malangbong Garut Regency, Board of Teachers / Subject Teachers Aqidah Morals, Students and Administrative Staff / TU) Documentation Study and in the examination using the technique of checking the validity of the data by the author as follows: Extension of participation., Observation persistence, Triangulation, Peer checking, Negative case analysis, Member checking, Detailed description, Dependency criteria and Data interpretation. 
IJIK, Vol. 9 No. 2: 48-60

Implementation Of Aqidah Akhlak Learning Using The Contextual Learning Model In Ma An-Nur

Malangbong Garut District

Lalan Jaelani

\section{RESULT AND DISCUSSION}

\section{Implementation of Moral Aqidah Learning by Using the Contextual Learning Model in MA An-Nur Malangbong, Garut Regency, Garut}

\section{Initial Assessment}

The results of the initial assessment by the researcher are used as the initial parameters to see the Islamic morals of the students before taking action and as a reference in preparing the orientation of the next Islamic moral enhancement program.

This research begins with initial observation, which is an orientation activity to find out the Aqidah Moral learning process that is usually done by teachers in shaping the Islamic character of students. This orientation is done to get a picture of what and how teachers and students in the learning process in the classroom. This is useful for considering actions to be taken to correct weaknesses and deficiencies in improving the Islamic character of students. Based on the results of interviews with students, students feel that so far the learning of the Aqidah Akhlak has been a bit fun, but rather feels bored when the lessons delivered too much using the lecture method.

Interviews with teachers were conducted to find out about learning that is usually carried out in class, especially in learning Aqidah Morals. The results obtained when the interview was conducted were the teachers often used the learning model, but for contextual learning, it was rarely done because the assumption was too complicated, too much time required.

Learning models that have been implemented by partner teachers are cooperative learning, jigsaw, role-playing, problem-solving. The contextual learning model has not been implemented because it sees complex learning stages. Based on the results of discussions with Aqidah Akhlak teachers agreed to apply the contextual learning model in Aqidah Akhlak subjects to shape the Islamic character of students carried out in Class XI MA An-Nur Malangbong.

Implementation or implementation of the use of contextual learning models in learning Aqidah Morals in MA An-Nur Malangbong is inseparable from the steps of its implementation. This is so that the implementation of Aqidah Akhlak learning will run more smoothly. According to Aqidah Moral MA teacher An-Nur Malangbong, there are several steps in implementing a contextual learning model in Aqidah Moral learning. These steps include before the learning or planning stage, learning implementation and after the learning implementation.

The implementation of contextual learning in the subjects of Aqidah Akhlak follows the flow as follows:

1. Planning, including learning objectives, learning planning, learning materials, methods used as well as the placement of time allocation, the implementation was carried out in September to November 2016. (Semester I of the 2016-2017 school year).

2. The implementation includes the whole process of learning activities before using the contextual learning model in Aqidah Akhla learning to improve the Islamic character of students.

3. Observations, carried out in conjunction with learning programs include teacher and student activities, learning methods, material development and student learning outcomes.

4. Reflection is an activity carried out to contemplate the results obtained from the actions taken. This reflection also becomes the basis for planning actions for the next cycle.

5. The research was carried out collaboratively with colleagues who assisted in observing and reflecting during the research. 
IJIK, Vol. 9 No. 2: 48-60

Implementation Of Aqidah Akhlak Learning Using The Contextual Learning Model In Ma An-Nur

Malangbong Garut District

Lalan Jaelani

The implementation of contextual learning models in improving the Islamic character of students can be seen from the observation sheet during the process, namely:

Table 1. Observation Results

\begin{tabular}{|c|c|c|}
\hline No & Aspects observed & Observation results \\
\hline 1 & $\begin{array}{l}\text { Conditioning students physically } \\
\text { and psychologically conducive learning } \\
\text { situations }\end{array}$ & $\begin{array}{l}\text { In the first cycle, the teacher only asks } \\
\text { students to prepare themselves to receive } \\
\text { learning but the next cycle the teacher has } \\
\text { conditioned the students physically and } \\
\text { psychologically so that students are better } \\
\text { prepared to learn }\end{array}$ \\
\hline 2 & $\begin{array}{l}\text { Appearance at the beginning of } \\
\text { learning }\end{array}$ & $\begin{array}{l}\text { The first cycle has been doing } \\
\text { apperception but has not touched on the } \\
\text { questions regarding the learning that will } \\
\text { take place, the next cycle the teacher has } \\
\text { made an apperception well }\end{array}$ \\
\hline 3 & $\begin{array}{l}\text { Deliver the learning objectives to } \\
\text { be implemented }\end{array}$ & $\begin{array}{l}\text { The learning objectives are } \\
\text { implemented but not yet complete }\end{array}$ \\
\hline 4 & $\begin{array}{l}\text { Developing students' thinking to } \\
\text { construct their knowledge }\end{array}$ & $\begin{array}{l}\text { Trying to dig into the knowledge of } \\
\text { students only occasionally through a few } \\
\text { questions, but the next cycle is to use } \\
\text { students' thinking more }\end{array}$ \\
\hline 5 & $\begin{array}{l}\text { Carry out inquiry activities on the } \\
\text { topics taught }\end{array}$ & $\begin{array}{l}\text { Doing questions and answers } \\
\text { learners try to find and find themselves } \\
\text { based on the themes to be taught }\end{array}$ \\
\hline 6 & $\begin{array}{l}\text { Develop the nature of students' } \\
\text { curiosity by raising questions }\end{array}$ & $\begin{array}{l}\text { Encourage students to raise questions } \\
\text { but more often the teacher asks }\end{array}$ \\
\hline 7 & Divide groups heterogeneously & $\begin{array}{l}\text { The teacher divides students by } \\
\text { counting from the front, then distributing the } \\
\text { numbers and colours of the flags to be used } \\
\text { as the name of the group }\end{array}$ \\
\hline 8 & $\begin{array}{l}\text { Carry out group activities through } \\
\text { discussion, question and answer }\end{array}$ & $\begin{array}{l}\text { The teacher carries out group } \\
\text { activities in each learning }\end{array}$ \\
\hline 9 & $\begin{array}{l}\text { Guiding students in working on } \\
\text { group assignments }\end{array}$ & $\begin{array}{l}\text { When students work on group } \\
\text { assignments the teacher guides them only at } \\
\text { the beginning of the cycle of guiding for one } \\
\text { group not by going around }\end{array}$ \\
\hline 10 & $\begin{array}{l}\text { Give rewards to groups that get the } \\
\text { best score }\end{array}$ & $\begin{array}{l}\text { Often reinforce the answers and } \\
\text { actions of students in completing their tasks }\end{array}$ \\
\hline
\end{tabular}


IJIK, Vol. 9 No. 2: 48-60

Implementation Of Aqidah Akhlak Learning Using The Contextual Learning Model In Ma An-Nur Malangbong Garut District

Lalan Jaelani

\begin{tabular}{|c|c|c|}
\hline & & $\begin{array}{l}\text { with just applause, then with praise, } \\
\text { reinforcement and so on }\end{array}$ \\
\hline 11 & Allow students to ask questions & Allow students to ask questions \\
\hline 12 & $\begin{array}{l}\text { Give a positive response to the } \\
\text { participation of students }\end{array}$ & $\begin{array}{l}\text { Often respond to each answer or } \\
\text { action in completing the task with applause, } \\
\text { then with praise, reinforcement and so on. }\end{array}$ \\
\hline 13 & $\begin{array}{l}\text { Involve students in the use of } \\
\text { media as a learning model. }\end{array}$ & $\begin{array}{l}\text { Sometimes and students also have to } \\
\text { be told to use props for the next cycle, more } \\
\text { students already do it }\end{array}$ \\
\hline 14 & $\begin{array}{l}\text { Doing reflection by involving } \\
\text { students after learning activities }\end{array}$ & $\begin{array}{l}\text { Reflecting with the guidance of the } \\
\text { teacher }\end{array}$ \\
\hline 15 & $\begin{array}{l}\text { Provide ability assessments for all } \\
\text { students }\end{array}$ & $\begin{array}{l}\text { In the first cycle only provides an } \\
\text { assessment of learning outcomes and then } \\
\text { has provided an assessment of learning } \\
\text { outcomes and in the form of a portfolio }\end{array}$ \\
\hline
\end{tabular}

Source: Researchers 2017

The results of the initial assessment were conducted by researchers based on findings in the field, namely the learning of Aqidah Morals towards improving the Islamic character of students in MA An-Nur Malangbong, Garut Regency, which most students still lack Islamic character. This is shown by the fact that there are still many students who have not been able to listen to the opinions of others, the ability to ask questions that are still low, do not have a sense of respect for what is conveyed by their friends, have not been able to work well in groups, especially in sharing morals where students have not been able to show mutual share material that is not yet understood or respond to problems faced by his friends. The results of the evaluation of Islamic characters which include the morals of al-Hikmah (wise), as-Syaja'ah (courageous), al-Alifah (friendship), morals of as-Syirkah (working together), and morals of as-Sakha (willing to share) enter in the low category.

Also, based on the observations and analysis of the research listed in Table 7 (attached) it can be seen that the Islamic morals of the students in learning the Aqidah Morals before implementing the contextual learning model as a whole reach an average of 2.44 meaning that the average Islamic morals of the participant's students are included in the sufficient category. The data above shows there are still many students who have not been able to share aspects and aspects of cooperation, especially in sharing knowledge with friends about material that has not been understood through peer tutors.

In the aspect of honest attitude, in this case, listening to the opinions of others reaches an average of 2.8 including the good category, this can be seen from the number of students who do not cheat in doing exams/tests, do not become plagiarism (taking/copying other people's work without mentioning the source), Expressing the feeling as it is, submitting to the authorities the goods found, making a report based on data or information as it is, and acknowledging errors or deficiencies that are owned.

For the aspect of discipline, attitudes obtained 2.35, including enough categories. This is evident when some students come not on time, do not obey the rules or rules together / school, do not do/collect assignments by the specified time, and follow the rules of written language that is good and right.

In the average category of responsibility, 2.44, including the medium category, this can be seen from students in carrying out individual tasks properly, accepting the risk of actions taken, not blaming/accusing others without accurate evidence, returning borrowed items, acknowledge and 
IJIK, Vol. 9 No. 2: 48-60

Implementation Of Aqidah Akhlak Learning Using The Contextual Learning Model In Ma An-Nur

Malangbong Garut District

Lalan Jaelani

apologize for mistakes made, keep promises, not blame others for our own mistakes, and carry out what has been said without being told/asked.

Morals work together with an average of 2.3 with enough categories, it appears in students who have not been able to accept friends in their groups, can not cooperate with the maximum, submit the results of group work to friends who he thinks are capable, can not appreciate the full difference opinion.

While for polite manners it reaches an average of 2.3 with enough categories this is apparent when students have not been as respectful as respecting older people, some sebgina students say dirty, rude, and arrogant, do not spit in any place, there are still students who interrupt the conversation at the wrong time, and many students who do not say thanks after receiving help from others.

Based on the results of the initial assessment, the researcher together with the Aqidah Akhlak MA teacher An-Nur Malangbong collaborated to plan the improvement of the Aqidah Akhlak subject to improve the Islamic character of the students. The improvement through the contextual learning model of learning is carried out in cycles consisting of four stages, namely learning planning, implementation, observation and carrying out reflection when learning is finished in each cycle. If in the first cycle the Islamic character of the students is still not optimal, then the learning process is improved again in the next planning cycle until researchers and teachers find a cycle that can change the learning process for the better, so that the Islamic character can improve.

\section{Learning Planning}

Based on the interview data conducted by the author, it is known that before conducting the PAI learning process, the teacher first makes a lesson plan using a contextual learning model. This RPP is made by the Aqidah Akhlak teacher by referring to the learning syllabus listed in the 2013 curriculum. For class XI, the RPP used is the RPP that has been made by the Aqidah Akhlak Teacher in which contains a contextual learning model.

\section{Learning Implementation}

From the results of observations made by the author obtained the following data: At the learning stage, the teacher divides the activities into three stages, namely preliminary, core and final activities. Preliminary activities, At this stage, what the teacher does is:

1. The teacher opens the learning by saying greetings, praying together led by a student with a solemn acceptance, the teacher starts the learning by reading the Koran chosen by one of the students, not forgetting the teacher checking the presence of students.

2. Teachers do apperception by asking students' insights regarding the material of stealing/corruption behaviour, do not forget the teacher asks students.

3. The teacher conveys basic competencies and learning objectives. The objectives to avoid the behaviour of stealing/corruption in the first meeting are that students can understand the meaning of stealing/corruption, the negative value of stealing/corruption, avoiding stealing/corruption behaviour, strategies to eradicate corruption and corruption.

4. The teacher conditions students physically and psychologically in a conducive learning situation. The teacher has prepared props to be used. Students are neatly seated ready to participate in learning.

5. The teacher conveys the stages of the activity to be carried out in learning. The stages are the stages of learning using a contextual learning model. 
IJIK, Vol. 9 No. 2: 48-60

Implementation Of Aqidah Akhlak Learning Using The Contextual Learning Model In Ma An-Nur

Malangbong Garut District

Lalan Jaelani

\section{Core activities}

At the core activity, the teacher uses the contextual learning model in the learning process starting from the observation stage. Learning activities carried out in the process of observing are reading, listening, seeing (without or with tools).

The second stage is asking. The questioning learning activity is carried out in a way; ask questions about the information that is not understood from what is observed or questions to get additional information about what is observed (Constructivism Stage).

With the motivation of the teacher, students ask about the theme of the subject they get. When the process of group discussion takes place, students are given the freedom to ask questions and find their learning resources by reading in textbooks or searching on the internet (Inquiry Phase).

The next stage is the teacher forms, student groups. Teachers from groups with the formation of 6 groups, the formation of groups is done by counting students from numbers 1 to 6 , repeated from numbers 1 to 6 and so on (Learning Community Stage). Then fellow numbers 1 or 2, 3 gather, and that's the group. In order not to be noisy, when gathering together numbers 1 or 2 may not speak, may only use gestures, may use hand signals or mouth movements. The grouping of students runs naturally, is heterogeneous, students come from various abilities and different backgrounds with the goal of all students can be active. One group consists of 5 or 6 students. After the group is formed, students gather with the group. Whereas group placement is not centred at one point, groups are scattered, some are in the right corner of the class, the left corner of the class and some are even outside the class so that they are more focused on working in their groups. The determination of group leaders is not determined by the teacher, but by each group. Usually what students do is that students in their groups raise their hands first, then in the count of 3 students in the group directly point out who is entitled to become the leader of the group. The ones that are appointed are the ones who have the right to be the chairman This is where the principle of democracy is implemented.

At this stage, the teacher distributes the subject matter to each group. The subject matter that must be discussed by each group is as follows:

Table 2. Distribution of subjects

\begin{tabular}{|c|c|l|}
\hline No & Kelompok & \\
\hline 1 & I & $\begin{array}{l}\text { Understanding stealing/corruption } \\
\text { behaviour }\end{array}$ \\
\hline 2 & II & The negative value of stealing/corruption \\
\hline 3 & III & Avoiding stealing/corruption behaviour \\
\hline 4 & IV & Strategy to eradicate corruption \\
\hline 5 & V & $\begin{array}{l}\text { Wisdom on the prohibition of } \\
\text { stealing/corruption }\end{array}$ \\
\hline
\end{tabular}


IJIK, Vol. 9 No. 2: 48-60

Implementation Of Aqidah Akhlak Learning Using The Contextual Learning Model In Ma An-Nur

Malangbong Garut District

Lalan Jaelani

\begin{tabular}{|c|c|l|}
\hline 6 & VI & $\begin{array}{l}\text { Examples of stealing/corruption in } \\
\text { society and its aftermath }\end{array}$ \\
\hline
\end{tabular}

Source: Processed by Researcher 2019

After getting the assignment from the teacher, students observe the pictures and text reading behaviour of stealing/corruption for further reading and observations about the theme of the subject matter obtained and write it on cardboard.

The fourth stage is the association. Learning activities carried out in the process of associating information is to process information that has been collected both limited from the results of the activities experiments as well as the results of observing activities and activities to collect information. At this stage, each group discusses the material that has been given to each group. Then, one person from each group is assigned to deliver the material to other groups in turns (Modeling Stage). Meanwhile, the group visited was writing information/knowledge delivered by one representative from each group. After finishing delivering the material to the other groups, one representative returned to their respective groups and discussed it again, as well as preparing several responses and arguments about other group material that had been submitted by each group representative.

The last step is communicating. Communicating learning activities are conveying the results of observations, conclusions based on the results of the analysis verbally, in writing or other media. In this activity, students alternately from each group present the results of the discussion, while the other groups pay attention or listen and respond

\section{Closing activities}

In this activity the teacher does is:

1. The teacher gives reinforcement material about avoiding the despicable moral stealing/corruption of material that has been studied together. This is done because maybe among students have not gained knowledge about avoiding the despicable character stealing/corruption completely and completely.

2. Teachers and students together conclude the material avoids the despicable character of stealing/corruption. The teacher asks several students to conclude, the last conclusion globally conveyed by the teacher.

3. The teacher conducts a post-test of students' understanding during the learning process. Posttests conducted in the form of oral tests and written tests. For oral tests, the teacher appoints several students to answer the questions asked by the teacher.

4. The teacher and the students reflect on the learning that has been carried out (Reflection Stage). At the reflection stage, the teacher asks the question of how students respond to learning using the contextual learning model, the result is that the average student answers feeling happy, busy, exciting, and not bored.

5. The teacher gives rewards to the best sellers, buyers and presenters. The reward is based on the assessment of teachers and students.

6. The teacher presents the material to be learned at the next meeting. The teacher conveys the material for the upcoming meeting is still the same material which is material to avoid the moral dishonesty of stealing/corruption, but students are invited to analyze the activities of stealing/corruption whose information is obtained by various sources and made in a simple paper. 
IJIK, Vol. 9 No. 2: 48-60

Implementation Of Aqidah Akhlak Learning Using The Contextual Learning Model In Ma An-Nur

Malangbong Garut District

Lalan Jaelani

7. The teacher gives independent assignments to students relating to the material to be learned at the next meeting.

8. Teachers and students express the moral message obtained from today's learning.

9. The teacher and students close the lesson by praying

\section{Assessment Stage}

The last stage of this learning process is the teacher conducts an assessment. Authentic assessment is carried out by the teacher in the form of classroom assessment through performance appraisals, written, and self-assessments which aim to measure attitudes, skills, and knowledge-based on process and results. The teacher conducts an assessment to measure the competence of knowledge to measure the ability, mastery and understanding of students related to the material to avoid the despicable character of stealing/corruption that they have learned and assignments in the form of project appraisal done in groups that are displayed in each group.

Based on the results of interviews with Aqidah morality teachers, that the implementation of Aqidah morality learning by using a contextual learning model is to:

1. Motivate to learn for students in the subject of Aqidah Akhlak by providing a new nuance of learning that is different from usual. As we know that the material Aqidah Akhlak is dogmatic, meaning students must agree on what is conveyed in the material even though they do not understand. The usual method of delivering the teaching usually uses the lecture method so that the delivery can be directly understood by students and there can be assignments in it, but the method makes the child bored and not active in learning. With this contextual learning model, it is hoped that dogmatic teachings can reach students in different ways and not make students passive.

2. To better provide an understanding of the concepts, understandings and facts that have been learned by students, so that what they learn has a meaningful value for themselves. This contextual learning model teaches students to learn to find their knowledge so that a strong concept is embedded so that the concept can be understood and understood by the students themselves, then after the students understand it can communicate to others.

3. Learning by involving them is believed to provide some kind of preparation and training in dealing with the reality of life in society. This learning method is centred on student activities. Students are active in finding their knowledge, understanding themselves and communicating with others. In the process, if students experience problems, the students must be able to solve the problem themselves.

4. Will develop an attitude of confidence, responsibility and a sense of social solidarity in dealing with various life problems. This contextual learning model is one of cooperative learning which is group learning. In group learning, students learn to discuss and learn responsibly to carry out the tasks of the teacher that must be done together, learn to accept differences, and learn to have a sense of solidarity. If there are problems in the group, the group members together to solve the problem.

\section{Action Observation}


IJIK, Vol. 9 No. 2: 48-60

Implementation Of Aqidah Akhlak Learning Using The Contextual Learning Model In Ma An-Nur

Malangbong Garut District

Lalan Jaelani

This observation activity the researcher did during the implementation of learning in class. By using the observation sheet the researcher records each stage that the teacher and students make in the learning situation.

In addition to conducting observations and interviews with Aqidah Akhlak teachers, the authors also conducted interviews with several students who have participated in Aqidah Akhlak learning using contextual learning models during learning from the beginning to the end and outside of learning, the results of the interview are as follows: Participants students recognize the use of contextual learning models for the first time in learning Aqidah Morals. In their school namely MA An-Nur Malangbong Garut new contextual learning models are used only for learning Aqidah Morals, no other subjects have used them yet.

Student responses to the use of contextual learning models in learning Aqidah Morals. The students stated that the learning of Aqidah Akhlak using the contextual learning model was very pleasant, this was evidenced by the enthusiastic attitude and enthusiasm of the students when they took part in the learning process. Student responses to group learning in learning Aqidah morals by using a contextual learning model. Students state that group learning in Aqidah Moral learning using contextual learning models is quite useful. The results of the author's interviews with several students who stated this they think that sometimes learning through group learning is less effective, this is because when learning groups some members do not want to work, do not want to be active, do not want to be given assignments, sometimes there are also group members who feel able to do their work so that other group members are not included to work together.

Students' responses to the contextual learning model that this learning model can give students the freedom to move (activities) in learning. This can be seen when students communicate with each other between groups by exchanging knowledge and materials around which indicates student activity in the learning process.

Other responses of students to this contextual learning model that this learning model can foster students' motivation to speak (express opinions) in learning. In this method, all students are allowed to express their opinions both in the group when the discussion takes place and when some students are assigned to explain the material knowledge to other groups.

Based on observations and assessment analysis listed in table 9 (attached) it can be seen that the Islamic character in the learning of the Aqidah Morals after the action model of contextual learning as a whole reaches an average of 3.3, meaning that the average Islamic character belongs to the very good category.

In the aspect of honest attitude, in this case, listening to the opinions of others reaches an average of 3.3 including the good category, this can be seen from the number of students who do not cheat in taking tests/tests, do not become plagiarism (taking/copying other people's work without mentioning the source), Expressing feelings as they are, submitting to the authorities the goods found, making a report based on data or information as it is, and acknowledging errors or deficiencies owned. For the aspect of discipline, attitudes obtained 3.25, including the very good category. This appears when students arrive not on time, adhere to the rules or rules of joint / school, collect assignments following the specified time, and follow the rules of written language that is good and right.

In the category of responsibility, an average of 3.44 is categorized as very good, this can be seen from students in carrying out individual tasks properly, accepting the risk of actions taken, not blaming/accusing others without accurate evidence, returning goods that are borrowed, acknowledge and 
IJIK, Vol. 9 No. 2: 48-60

Implementation Of Aqidah Akhlak Learning Using The Contextual Learning Model In Ma An-Nur

Malangbong Garut District

Lalan Jaelani

apologize for the mistakes made, keep promises, do not blame others for our own mistakes, and carry out whatever said without being told/asked.

Morals work together with an average of 3.26 with a very good category this is seen in students who can accept friends in the group, can work together with the maximum, submit the work of the group to friends who he considers capable, can appreciate the full difference of opinion.

While for polite manners it reaches an average of 3.4 with a very good category this is seen when students respect older people, students do not speak dirty, rude, and arrogant, do not spit in any place, there are no students who interrupted the conversation at the wrong time, and many students who are used to saying thank you after receiving help from others.

\section{CONCLUSION}

After the author conducts research on the implementation of Aqidah Akhlak learning with contextual approaches in Madrasah Aliyah An-Nur Malangbong Garut Regency, then conducts an analysis supported by the theories contained in the previous chapter, the conclusions can be drawn as follows: Learning design plays an important role in improving the quality of learning. Aqidah moral learning design implemented at MA An-Nur Malangbong includes: 1) identifying learning objectives, 2) conducting instructional analysis, 3) analyzing student characteristics and learning context, 4) formulating specific learning objectives, 5) developing research instruments, 6) develop learning strategies, 7) develop and select teaching materials, 8) design and develop formative evaluations, 9) make revisions to learning programs and 10) design and develop summative evaluations. The learning design is designed in an RPP by Aqidah Akhlak teachers with contextual learning approaches namely constructivism, contrivance, questioning, learning community, learning community, modelling, reflection, reflection and reflection, and assessment. actually (authentic assessment). The implementation of Aqidah Akhlak learning with a contextual approach implemented in Madrasah Aliyah An-Nur already Malangbong has implemented the CTL components as mentioned in the learning design.

Aqidah learning morality by using a contextual approach carried out at MA Annur Malangbong Kab. Arrowroot is inseparable from the supporting and inhibiting factors. Supporting factors include the principal's leadership factor that has the managerial ability and high professional integrity, the parent support factor and the madrasa committee that is participatory and cooperative with school policy, the teacher's mental attitude that is always consistent, the ability of qualified teachers, teaching aids/media adequate, and conducive environment. While the inhibiting factors include: difficulties in dealing with individual differences in students, difficulties in determining material suitable for the use of contextual approaches, difficulties in obtaining learning tools, difficulty in conducting evaluations and time management, difficulties in communicating verbally / discussing, feelings of doubt and embarrassed, requires a lot of time, and questions and answers are not relevant to the material. A contextual approach to the subjects of Aqidah Morals carried out at MA An-Nur Malangbong Kab. Arrowroot with the formation of Islamic character in students can be said to be very effective. This can be seen from the results of observations, interviews and assessments conducted during the learning process. For the five Islamic characters analyzed are wise characters (al-Hikmah), brave characters (as-Syaja'ah), friendship characters (al-Alifah), cooperation characters (as-Syirkah), and characters willing to share (as-Sakha), an average increase of initially 6.4 to 8.1 . 
IJIK, Vol. 9 No. 2: 48-60

Implementation Of Aqidah Akhlak Learning Using The Contextual Learning Model In Ma An-Nur

Malangbong Garut District

Lalan Jaelani

\section{REFERENCES}

Al Baehaqi, A. K., \& Haris, D. (2015). Penggunaan Tehnik Bermain Peran (Role Play) Untuk Meningkatkan Kemampuan Menyimak Mahasiswa Dalam Mata Kuliah Listening In Professional Context Ii Pada Mahasiswa Semester Tiga. Majalah Ilmiah Solusi, 1(04).

Asy'ari, M., Ekayati, I. N., \& Matulessy, A. (2014). Konsep Diri, Kecerdasan Emosi Dan Motivasi Belajar Siswa. Persona: Jurnal Psikologi Indonesia, 3(01).

Darmadi, H. (2016). Tugas, Peran, Kompetensi, Dan Tanggung Jawab Menjadi Guru Profesional. Edukasi: Jurnal Pendidikan, 13(2), 161-174.

Hadi, S. (2012). Evaluasi Implementasi Kurikulum Berbasis Kompetensi Pada Lembaga Kursus Dan Pelatihan (Lkp) Program Otomotif Diy. Jurnal Pendidikan Vokasi, 2(2).

Hermayanti, P., Budimansyah, A., \& Lenggana, U. T. (2018). Implementasi Metode Scoring System Sebagai Paramater Dalam Memahami Kajian Ilmu Tasawuf Berbasis Android. Jurnal Online Informatika, 2(2), 92-101.

Moleong, L. J. (2012). Metodologi Penelitian Kualitatif. Bandung: Remaja Rosdakarya.

Muhibbin, S. (2010). Psikologi Pendidikan Dengan Pendekatan Baru. Bandung: Pt Remaja Rosdakarya.

Pransiska, T. (2016). Konsepsi Fitrah Manusia Dalam Perspektif Islam Dan Implikasinya Dalam Pendidikan Islam Kontemporer. Jurnal Ilmiah Didaktika: Media Ilmiah Pendidikan Dan Pengajaran, 17(1), 1-17.

Sugiyono. (2013). Metode Penelitian Pendidikan Pendekatan Kauntitatif, Kualitatif Dan R\&D. Bandung: Alfabeta.

Tafsir, A. (2017). Filsafat Pendidikan Islam (R. Rosdakarya, Ed.). Bandung: Remaja Rosdakarya.

Uce, L. (2016). Realitas Aktual Praksis Kurikulum: Analisis Terhadap Kbk, Ktsp Dan Kurikulum 2013. Jurnal Ilmiah Didaktika: Media Ilmiah Pendidikan Dan Pengajaran, 16(2), 216-229.

Zayadi, A., \& Majid, A. (2016). Tadzkirah: Pembelajaran Pendidikan Agama Islam (Pai) Berdasarkan Pendekatan Kontekstual. Rajagrafindo Persada. 